\title{
Intervention by (secret) invitation: searching for a requirement of publicity in the international law on the use of force with consent.
}

\author{
Max Brookman-Byrne*
}

\begin{abstract}
In light of evolving practices of conflict - the move to remote, light-foot, long-term, 'liquid' interventions - interrogations into the manner in which one state can consent to the use of force by another on its territory (intervention by invitation) have become increasingly pressing. In Pakistan, the US carried out remote airstrikes for nine years on the basis of secret consent, raising the question of how secrecy impacts upon the validity of consent to the use of force: whether secrecy renders consent invalid or, put differently, whether valid consent contains a requirement of publicity. Examining, state responsibility, jus ad bellum, and examples of state practice between 1944 and the present, this article considers the question of publicity, finding that, though there is a tendency towards the publication of consent, in a doctrinal legal sense there is insufficient evidence to suggest an obligation to publicise. This article argues that, due to the absence of such a requirement, consent is not a rule that restricts the use of force, but one that enables it; it is a doctrine that lends itself to the service of hegemony and the projection of power by states, and it must be recognised as such.
\end{abstract}

Use of force; intervention by invitation; consent; secrecy; modern warfare

\section{Introduction}

In Pakistan, on Thursday the $17^{\text {th }}$ of June 2004, Nek Muhammad and several of those around him, including two children, were killed by a missile strike that, literally, came out of the blue. ${ }^{1}$ Muhammed was the commander of a group that supported the Taliban and had long been engaged in conflict with the government of Pakistan. ${ }^{2}$ Having been sought by the Pakistani military for a week prior to his death, the successful strike was heralded by officials as a victory which 'sends a good message' that 'the government [of Pakistan] is serious. The government means business. ${ }^{3}$ In addition to celebrating the strike, the military explicitly took ownership

\footnotetext{
* University of Lincoln, mbrookmanbyrne@lincoln.ac.uk. This paper was first presented at the 'What Room for Military Assistance on Request' conference, organised by the Ghent Rolin-Jaequemyns International Law Institute, and the Journal on the Use of Force and International Law. Thanks go to the organisers of the conference, and to my fellow participants and attendees for providing very useful feedback, as well as thoughts for future work. The hosts deserve extra credit for serving by far the best beer I have ever had during an academic conference. Thanks also are particularly due to Professor James A Green and Faye Bird for some very insightful comments on the first draft. All websites last accessed 15 March 2020.

${ }^{1}$ David Rohde and Mohammed Kahn, 'The Reach of War: Militants; Ex-Fighter for Taliban Dies in Strike in Pakistan' New York Times (Rawalpindu and Peshawar, 19 June 2004) https://www.nytimes.com/2004/06/19/world/the-reach-of-war-militants-ex-fighter-for-taliban-dies-in-strike-inpakistan.html.

${ }^{2}$ Rahimullah Yusufzai, 'Profile: Nek Mohammed' BBC (Peshawar, 18 June 2004) http://news.bbc.co.uk/1/hi/world/south asia/3819871.stm./

${ }^{3}$ Rohde and Kahn (n 1).
} 
of it, with one general stating that 'he was killed ... by our hand', discussing reported sightings of a US drone as 'absurd'. 4

In fact, the opposite was true. The strike was the culmination of a secret agreement between the United States' (US) Central Intelligence Agency (CIA) and Pakistan's Inter-Services Intelligence (ISI) in which the US agreed to kill Muhammad in exchange for permission to carry out covert drone strikes throughout the region of Waziristan. ${ }^{5}$ This was an example of intervention by invitation, ${ }^{6}$ a basis for the lawful resort to the use of force; however, on this occasion, the invitation was kept secret. So began the US drone programme in Pakistan, an operation based on covert consent provided by the government, which was kept secret until 2013 when confidential memos revealing its existence were passed to The Washington Post. ${ }^{7}$ During that time, approximately 378 drone strikes were carried out, killing an estimated 2,2983,690 people, $421-958$ of who were civilian. ${ }^{8}$ In 2013 , consent was publicly withdrawn, ${ }^{9}$ though since then 51 further strikes have been reported ${ }^{10}$ leaving open the possibility that consent continues to be provided in secret.

The US campaign in Pakistan is an example of the late-modern trend towards a practice that has been termed 'liquid warfare', in which military intervention is characterised by fluidity, flexibility and mobility, in contrast to more protracted and cumbersome large-scale conflicts. ${ }^{11}$ One aspect of liquid warfare that international relations scholars have highlighted is the presence of various degrees of partnership between actors involved in conflicts. ${ }^{12}$ This exemplifies the importance of consent within the legal architecture of liquid warfare, it being a legal justification for the use of force with an emphasis on partnership. Considering the use of secret consent as integral to liquid warfare operations in Pakistan invites engagement with a novel question in terms of the legal doctrine of intervention by invitation: whether the lawfulness of military interventions conducted with consent is compromised by that consent having been given in secret. Put differently, we may ask whether consent to the use of force contains a requirement of publicity.

\footnotetext{
${ }^{4}$ Ahsunullah Wazir, 'Renegade Tribal Leader Slain: Pakistani Forces Kill Leader Allied with Suspected alQaida Gunmen' Vancouver Sun (Wana, 19 June 2004) (emphasis added).

${ }^{5}$ Mark Mazzetti, 'A Secret Deal on Drones, Sealed in Blood' New York Times (6 April 2013)

https://www.nytimes.com/2013/04/07/world/asia/origins-of-cias-not-so-secret-drone-war-inpakistan.html?pagewanted=all.

${ }^{6}$ Within this article, 'intervention by invitation' and phrases such as 'consent to the use of force' are used interchangeably. There is important work to be done in terms of the language surrounding consensual interventions, and the activity or passivity of territorial states implied by 'invitation' or 'consent' respectively, however this issue cannot be adequately addressed in this piece.

${ }^{7}$ Greg Miller and Bob Woodward, 'Secret Memos Reveal Explicit Nature of US, Pakistan Agreement on Drones' Washington Post (24 October 2013) http://www.washingtonpost.com/world/national-security/toppakistani-leaders-secretly-backed-cia-drone-campaign-secret-documents-show/2013/10/23/15e6b0d8-3beb11e3-b6a9-da62c264f40e story.html.

8 'CIA and US Military Drone Strikes in Pakistan, 2004 to Present' (The Bureau of Investigative Journalism) https://docs.google.com/spreadsheets/d/1NAfjFonM-Tn7fziqiv33HlGt09wgLZDSCPBQaux51w/edit\#gid=1436874561.

${ }^{9}$ Miller and Woodward (n 7).

${ }^{10}$ The Bureau of Investigative Journalism (n 8).

${ }^{11}$ See, for instance, Jolle Demmers and Lauren Gould, 'An Assemblage Approach to Liquid Warfare: AFRICOM and the 'Hunt' for Joseph Kony' (2019) 49(5) Security Dialogue 364; Max M Mutschler, 'On the Road to Liquid Warfare? Revisiting Zygmunt Bauman's Thoughts on Liquid Modernity in the Context of the "New Western Way of War"” (2016) Bonn International Center for Conversion Working Paper 3/2013.

12 Demmers and Gould (n 11), 366.
} 
Of course, beyond modern liquid warfare, the question of the necessity of publicising consent equally impacts more traditional (territorially and temporally restricted) modes of warfare. However, my contention is that the current moment of expanding resort to remote and liquid approaches ${ }^{13}$ has dramatically increased the urgency of academic engagement with the issue of secret consent, which has thus far received scant attention within the literature. ${ }^{14}$

Given the capacity of consent to provide states with the ability to carry out lawful uses of force, the absence of a sustained and in-depth examination of the phenomenon of secret consent presents a material and significant gap in the literature. This article addresses this gap by considering whether there is a basis upon which to ground a publicity requirement within the doctrine of intervention by invitation or whether, conversely, the use of force may be conducted lawfully in the event that consent has been given secretly. As this research is relevant to all forcible interventions carried out with consent it has very broad implications for the use of force.

In interrogating this question, the work will first set out the concept of liquid warfare as an account of modern practices of conflict. It will then briefly set out the basic framework of intervention by invitation, before applying this to US operations in Pakistan, concluding that these satisfy the basic requirements of the framework. Having concluded thus, the work will consider whether the secrecy of Pakistan's consent impacts on the lawfulness of the intervention, looking for a requirement of publicity within state responsibility, ${ }^{15}$ the rules governing the use of force, and the practice of states. Finally, having found that there is no publicity requirement, it will be argued that the doctrine of intervention by invitation provides an impoverished basis for restricting the use of force and that ultimately it enables practices that draw on and perpetuate colonial techniques of domination using air power. This paper calls for a re-evaluation of the doctrine of intervention by invitation as a restriction on the use of force, and a recognition of its potential complicity in engendering the ability of powerful states to use force, and in supporting increased militarism.

\section{Consent and modern 'liquid' warfare}

During the $21^{\text {st }}$ century, the nature of Western-led conflict has undergone somewhat of a metamorphosis. Largescale 'boots on the ground' interventions, such as NATO's operations in Afghanistan and Iraq, have been replaced by a light-footed approach comprising elements such as counter-terrorism and stabilisation, as well as capacity building and training. ${ }^{16}$ In part a product of global recession and defence budget cuts militating against 'asymmetric wars with a parallel commitment to large-scale nation-building projects' ${ }^{17}$ the move towards lighter presence within battle zones is argued also to have been prompted by the proliferation of increasingly 'remote' technologies, allowing violent intervention without the presence of ground troops. ${ }^{18}$ This sits within a more general shift, certainly within the US military, towards

\footnotetext{
${ }^{13}$ Emily Knowles and Abigail Watson, 'Remote Warfare: Lessons Learned from Contemporary Theatres' (2018) Oxford Research Group: Remote Warfare Project, 4-5.

${ }^{14}$ The one brief mention that it has received is in Sikander Ahmed Shah's monograph on drone use in Pakistan: Sikander A Shah, International Law and Drone Strikes in Pakistan: the Legal and Socio-Political Aspects (Routledge 2015) 102.

${ }^{15}$ Insofar as they are relevant and analogous to the law on the use of force.

${ }^{16}$ Knowles and Watson (n 16), 2.

${ }^{17}$ Andrew Mumford, 'Proxy Warfare and the Future of Conflict' (2013) 158(2) RUSI Journal 40, 42.

${ }^{18}$ Caroline Holmqvist, 'Undoing War: War Ontologies and the Materiality of Drone Warfare' (2013) 41(3) Millennium: Journal of International Studies 535, 539.
} 
greater secrecy and the increased use of covert assets such as special forces. ${ }^{19}$ Finally, there has been a trend towards greater permeability in the boundaries-both geographical and temporal — of armed conflict; the wars in Iraq and Afghanistan heralding the emergence of 'the everywhere war' of open-ended scope, seemingly lasting indefinitely and taking place in and across border zones. ${ }^{20}$

International relations and security studies scholars have referred to this new approach to conflict as 'liquid warfare', drawing on Zygmunt Bauman's concept of 'liquid modernity' in which power has rejected 'territorial confinement', instead functioning through 'escape, slippage, elision and avoidance'. ${ }^{21}$ For Demmers and Gould, liquid warfare is about 'flexible, open-ended, "pop-up" military interventions, supported by remote technology and reliant on local partnerships and private contractors, through which (coalitions of) parties aim to promote and protect interests'. ${ }^{22}$ For Mutschler, it is about mobility, precision and inaccessibility (of the state waging liquid warfare), as well as 'the avoidance of responsibilities and costs that come along with the control over territory. ${ }^{23}$ Liquid warfare is thus characterised principally by dynamism.

The reliance on 'local partnerships' within the contemporary turn to liquid warfare operations ${ }^{24}$ highlights the central role played by consent in this type of conflict. The consent of a state to intervention enables intervening states to conduct remote operations against non-state armed groups with far greater mobility than would otherwise be possible, while eliminating the need to exert territorial control. In a practical sense, it means weapons systems such as drones, that would otherwise be susceptible to being shot down by a state's air defences, are able to be flown with relative ease. In a legal sense, the emphasis on partnership means that consent provides a key legal bases for such interventions and so is deeply imbricated within the practice of liquid warfare. To take US operations as an example, consent has been arguably the central plank in the process of legitimising extraterritorial drone strikes against al-Qaeda and related groups. $^{25}$

As well as liquidity and partnership, modern warfare is often secret. ${ }^{26}$ Though the general existence of a campaign may be acknowledged, the specifics of operations remain covert. Exemplifying this, US remote operations against non-state armed groups have been carried out for a long time in secret ${ }^{27}$ and it is claimed that the US government has only ever acknowledged around 20 percent of its remote airstrikes. ${ }^{28}$ The secrecy and obfuscation surrounding these operations also extends to their legal basis: while claims to generalised self-defence against

\footnotetext{
${ }^{19}$ Ibid, 539; Jennifer D Kibbe, 'Conducting Shadow Wars' (2012) 5(2) Journal of National Security Law and Policy 373.

${ }^{20}$ Derek Gregory, 'The Everywhere War' (2011) 177(3) Geographical Journal 238.

${ }^{21}$ Demmers and Gould (n 11), 366; Mutschler (n 11), 8.

22 Demmers and Gould (n 11), 366.

${ }^{23}$ Mutschler (n 11), 13.

${ }^{24}$ Demmers and Gould (n 11), 366.

${ }^{25}$ Max Byrne, 'Consent and the Use of Force: An Examination of "Intervention by Invitation" as a Basis for US Drone Strikes in Pakistan, Somalia and Yemen' (2016) 3(1) Journal on the Use of Force and International Law 91.

${ }^{26}$ Kibbe (n 19).

${ }^{27}$ Philip Alston, 'The CIA and Targeted Killings Beyond Borders' (2011) 2 Harvard National Security Journal 283, 328-30.

28 'Out of the Shadows: Recommendations to Advance Transparency in the Use of Lethal Force' (Columbia Law School Human Rights Clinic and Sana’a Center for Strategic Studies, 2017) https://static1.squarespace.com/static/5931d79d9de4bb4c9cf61a25/t/5a0b6ea224a6941e715f3da4/15106986667 40/5764 HRI+Out+of+the+Shadows-WEB.PDF 3.
} 
'al-Qaeda, as well as the Taliban and associated forces' ${ }^{29}$ have been made, there has been effective silence as to the actual contours of the legal justification underpinning the US's extraterritorial attacks against various non-state armed groups. In Pakistan, where US drones carried out at least 430 airstrikes between 2004 and $2018,{ }^{30}$ consent was secretly given in $2004 .{ }^{31}$ Indeed, documents leaked through Wikileaks indicate that between 2007 and 2011 the government of Pakistan and the CIA cooperated closely, though in complete secrecy. ${ }^{32}$

Given the confluence of secrecy and consent within modern liquid warfare operations, the need to engage with the lawfulness of secret consent is clear. That is not to say that the issues of secret consent and the conclusions reached within this article are unique to liquid warfare, they apply equally to any use of force on the basis of secret or otherwise unpublished consent to intervention. Nevertheless the impetus behind this work is the fact that in Pakistan, up to 3,690 people were killed via covert operations that drew extensive legal justification from the provision of secret consent. If secret consent provides a viable avenue to proclaim the lawfulness of uses of force of this nature then the law as it stands is complicit in the proliferation of this form of conflict. Ultimately, a legal framework that permits secret consent should not be considered to be one that provides realistic curbs on the use of force but instead as an enabler of force and the militarism of powerful states.

The next section will set out the standard legal picture of intervention by invitation, before applying it to the US intervention in Pakistan at the request of the state government. Assessing that consent has been lawfully, though secretly, given in that situation, the work will consider whether there is a basis upon which the use of force may be unlawful as a result of the failure to publicise consent.

\section{Intervention by invitation within international law}

There have been numerous engagements with the doctrine of intervention by invitation ${ }^{33}$ and it is beyond the scope of this paper to delve into the minutiae of these legal debates, many of which are addressed elsewhere in this special issue. Nevertheless, in order to provide legal context it is necessary to consider a brief sketch of how consent operates.

The ability of a state to consent to an intervention is an operationalisation of sovereignty over its domestic jurisdiction, as reflected in Article 2(7) of the UN Charter. Consent to external interventions is a fundamental consequence of a state's legal personality within international law. That a state can consent to intervention has been widely recognised by international bodies. ${ }^{34}$ My view is that intervention by invitation is not an exception to the prohibition of the

\footnotetext{
${ }^{29}$ Harold H Koh, 'The Obama Administration and International Law' (US Department of State, 25 March 2010) https://2009-2017.state.gov/s/1/releases/remarks/139119.htm.

30 'Drone Strikes in Pakistan' (The Bureau of Investigative Journalism) https://www.thebureauinvestigates.com/projects/drone-war/pakistan.

${ }^{31}$ Mazzetti (n 5).

${ }^{32}$ Miller and Woodward (n 7).

${ }^{33}$ See, for instance, Karine Bannelier-Christakis, 'Military Interventions against ISIL in Iraq, Syria and Libya, and the Legal Basis of Consent' (2016) 29(3) Leiden Journal of International Law 743; Erika de Wet, 'The Modern Practice of Intervention by Invitation in Africa and its Implications for the Prohibition of the Use of Force' (2016) 26(4) European Journal of International Law 979; Laura Visser, 'May the Force be with You: The Legal Classification of Intervention by Invitation' (2019) 22(1) Netherlands International Law Review 21; ${ }^{34}$ See, for instance, Case Concerning Military and Paramilitary Activities in and Against Nicaragua (Nicaragua v United States of America) (merits) [1986] ICJ Reports 14, para 246; General Assembly Resolution 3314 (XXIX) Definition of Aggression (1974), Article 3(e).
} 
use of force under Article 2(4) of the Charter but rather avoids engaging the rule entirely. If a use of force has prior consent or is invited, it is not carried out 'against the territorial integrity or political independence' of a state and therefore cannot be seen as a breach of Article 2(4); ${ }^{35}$ where there is consent to the use of force, Article 2(4) is 'inoperative'. ${ }^{36}$ Likewise, the ICJ has asserted that interventions that have been requested by states will not violate the principle of non-intervention, rather than being breaches of the principle which are excused after the fact. ${ }^{37}$ This contrasts with the exceptions to the prohibition, such as self-defence or UN Security Council (UNSC) authorisation, which are permitted violations. ${ }^{38}$ Consent therefore presents a powerful tool for states to legitimise (both in law and public opinion) forcible interventions.

To assert the lawfulness of an intervention by virtue of consent requires satisfaction of the doctrine's constituent elements. However, being a manifestation of sovereignty, it is difficult to pin down specific necessary modalities required for consent to be operative, other than that it must actually represent the will of the state expressed through the government.

In the context of the law of state responsibility, the International Law Commission (ILC) has asserted that consent must be 'valid' 39 but the constitution of validity depends on whatever primary rule of international rule is implicated by the act in question. ${ }^{40}$ This is reflective of debates during the drafting of the Draft Articles on State Responsibility (DASR) as to whether consent should even be included as a circumstance precluding wrongfulness, given that prior consent has the effect of removing the possibility of wrongfulness per se, thereby rendering the relevant rule inoperative. ${ }^{41}$ Indeed, such is the apparent redundancy of consent in this situation that the special rapporteur suggested that it should be removed from the DASR. ${ }^{42}$ Regardless, consent made it into the ILC's final draft articles and Article 20 gives what can be regarded as a loose framework for interrogating the validity of consent: it must be 'freely given' by a person or body with the 'authority to consent', 'clearly established', and not 'vitiated by error, fraud, corruption or coercion' ${ }^{43}$ These basic elements accord with the notion that consent must actually reflect the will of the state; anything less would clearly not be an exercise of sovereignty.

Thus, consent to the use of force will be valid where it satisfies these basic elements, as well as any additional ones that arise as a function of the primary rule. The Institut de Droit International's (IDI) resolution on the use of military assistance on request emphasises the need

\footnotetext{
${ }^{35}$ Tom Ruys and Luca Ferro, 'Weathering the Storm: Legality and Legal Implication of the Saudi-Led Military Intervention in Yemen' (2016) 65 International and Comparative Law Quarterly 61, 79; Benjamin Nußberger, 'Military Strikes in Yemen in 2015: Intervention by Invitation and Self-Defence in the Course of Yemen's "Model Transitional Process"' (2017) 4(1) Journal on the Use of Force and International Law 110, 125; Cóman Kenny and Seán Butler, 'The Legality of Intervention by Invitation in Situations of R2P Violations' (2018) 51 New York University Journal of International Law and Politics 135, 138-9. For an alternative view, see de Wet (n 33), 980.

${ }^{36}$ ILC, Summary Records of the Meetings of the Thirty-First Session (14 May-3 August 1979) Yearbook of the International Law Commission 1979, Vol I, $1538^{\text {th }}$ Meeting, para 29. See also, Karine Bannelier and Theodore Christakis, 'Under the UN Security Council's Watchful Eyes: Military Intervention by Invitation in the Malian Conflict' (2013) 26 Leiden Journal of International Law 855, 860.

${ }^{37}$ Nicaragua (n 34), para 246.

${ }^{38}$ ILA, Sydney Conference (2018), Final Report on Aggression and the Use of Force, 612.

${ }^{39}$ Draft Articles of State Responsibility (2001) UN Doc A/56/10 (DASR), Article 20.

${ }^{40}$ DASR, Article 20, para 4.

${ }^{41}$ ILC (n 36), para 7.

${ }^{42}$ Second Report on State Responsibility, by Mr James Crawford, Special Rapporteur (30 April 1999) UN Doc A/CN.4/498/Add.2, para 241.

${ }^{43}$ DASR, Article 20, para 6.
} 
for 'free expression', ${ }^{44}$ as well as for a request to be 'valid' and 'specific', ${ }^{45}$ terms which do not provide much clarity beyond Article 20 DASR. Commentary on the use of force with consent has broadly adopted the basic elements under Article 20 DASR. ${ }^{46}$ Where relevant, these have been adapted to suit the gravity of military intervention, for instance by recognising that only the highest authority of the state has the capacity to give consent to the use of force. ${ }^{47}$

Arising out of the need for consent to be given by a government that reflects the will of the state, governmental legitimacy is repeatedly identified as a key determinant of the validity of consent to the use of force. ${ }^{48}$ At its most basic, this means that rebel groups are incapable of validly requesting military intervention as part of a struggle against a government. ${ }^{49}$ The understandable need for governmental legitimacy also raises questions where the incumbent government has tenuous legitimacy, for instance in situations where it lacks effective control over territory as a result of conflict. Reflecting this, the IDI resolution limits the ability of a government to request military intervention to situations that are below the threshold of noninternational armed conflicts under Article 1 of Additional Protocol II to the Geneva Conventions. ${ }^{50}$ This categorical severance of the point at which consent can be given is subject to a great deal of controversy within the literature, with division between scholars as to the point at which a government can no longer give valid consent to external intervention. According to the notion of 'negative equality', during a period of 'civil war' neither rebels nor government may invite intervention as to do so would be to interfere with a people's right to determine its own future. ${ }^{51}$ Conversely others, while recognising the importance of effective control, have suggested that continued international recognition of a government provides a beleaguered regime with ongoing authority to request intervention. ${ }^{52}$ Further, there is debate around the extent to which democratic legitimacy impacts upon the recognition of a government and consequently its ability to invite military intervention. ${ }^{53}$ Elsewhere it has been suggested that the purpose of an intervention is crucial to assessing the validity of consent, such that consent from a government with impaired effective control may be lawful where the purpose of intervention is to combat terrorism, rather than to settle an internal struggle in favour of the incumbent regime. ${ }^{54}$ Governmental legitimacy is clearly pivotal in establishing the

\footnotetext{
${ }^{44}$ Institut de Droit International, Present Problems of the Use of Force in Internatioanl Law $10^{\text {th }}$ Commission, Sub-Group C-Military Assistance on Request, Resolution (8 September 2011) Article 1.

45 Ibid, Article 4(2).

${ }^{46}$ Gregory Fox, 'Intervention by Invitation' in Marc Weller (ed) The Oxford Handbook of the Use of Force in International Law (Oxford University Press 2015) 830.

${ }^{47}$ Ruys and Ferro (n 35), 81; Nußberger (n 35), 126; Visser (n 33), 29-30.

${ }^{48}$ Louise Doswald-Beck, 'The Legal Validity of Military Intervention by Invitation of the Government' (1986)

56(1) British Yearbook of International Law 189, 191-2; Fox (n 46), 818; de Wet (n 33); Bannelier and

Christakis (n 36), 860.

${ }^{49}$ Nicaragua (n 34), para 246.

${ }^{50}$ Such a non-international armed conflict is one between the government of a state and an armed group (or groups) under responsible command, and which exercise sufficient control over territory to enable sustained and concerted military operations: Protocol Additional to the Geneva Conventions of 12 August 1949, and relating to the Protection of Victims of Non-International Armed Conflicts (adopted 8 June 1977, entered into force 7 December 1978) 1125 UNTS 609 (Additional Protocol II) Article 1(1). This is distinct from the lower threshold of a non-international armed conflict under common Article 3 of the Geneva Conventions, which is reached where fighting is sufficiently intense and the non-state armed group sufficiently organised: Prosecutor v Tadić (Decision on the Defence Motion for Interlocutory Appeal on Jurisdiction) IT-94-1-AR72 (2 October 1995), para 70 .

${ }^{51}$ Fox (n 46), 827.

52 Doswald-Beck (n 48), 199-200.

53 de Wet (n 33), 989-90.

${ }^{54}$ Bannelier and Christakis (n 36), 864
} 
validity of consent but it is not for this work to provide a determination as to what constitutes such legitimacy.

The above can therefore be viewed as providing a loose framework for assessing the validity of consent in relation to the use of force generally, which will now be used to demonstrate the ostensible legitimacy of Pakistan's consent to the liquid warfare intervention carried out by the US.

\section{US intervention in Pakistan}

North Waziristan in Pakistan has been one of the key theatres for US airstrikes conducted against 'al-Qaeda, the Taliban and associated forces'. ${ }^{55}$ Running from 2004 until an apparent hiatus starting in mid-2018, the US has conducted an estimated minimum of 430 airstrikes from armed drones in the region, which have produced a death toll of between 2,515 and 4,026. ${ }^{56}$ Many of these strikes target members of the Haqqani Network, an insurgent group based in Afghanistan and North Waziristan which has supported the Afghan Taliban and fought against the US as part of the war in Afghanistan. ${ }^{57}$ Other airstrikes have targeted members of Tehrik-i-Taliban Pakistan (TTP) and a Pakistan-based franchise of al-Qaida, groups which are not directly involved in the war in Afghanistan. The airstrikes therefore comprise a portion that are part of a 'spillover' conflict, and the rest that may be considered counter-terrorism.

Conducted almost exclusively without 'boots on the ground' and with heavy reliance on remote technology, the US operation in Pakistan is a clear example of liquid warfare: the use of MQ1B Predator and MQ-9 Reaper drones has enabled the US to carry out an operation that is openended, 'pop-up' and flexible. ${ }^{58}$ The Reaper and Predator drones are flown by pilots at an undisclosed US military base far from where the missiles impact, ${ }^{59}$ and each possesses a loiter time of up to 14 hours, ${ }^{60}$ advanced targeting systems and guided munitions. ${ }^{61}$ As such these weapons systems enable the projection of US military force with a fluidity that would be unavailable to troops confined to the ground, or even to traditional jets which are bound by factors such as pilot fatigue.

Crucially, the US drone campaign in Pakistan is secret: under the Bush and Obama administrations, drone attacks in Pakistan were carried out by the CIA and classified as covert, ${ }^{62}$ a practice that has continued under Trump. ${ }^{63}$ The expansion of the programme under

\footnotetext{
${ }^{55}$ See, for instance, Koh (n 29).

${ }^{56}$ The Bureau of Investigative Journalism (n 8).

57 'Haqqani Network' (Stanford Center for International Security and Cooperation)

https://cisac.fsi.stanford.edu/mappingmilitants/profiles/haqqani-network.

${ }^{58}$ Demmers and Gould (n 11), 366.

${ }^{59}$ Greg Miller and Julie Tate, 'CIC Shift Focus to Killing Targets' Washington Post (1 September 2011)

https:/www.washingtonpost.com/world/national-security/cia-shifts-focus-to-killingtargets/2011/08/30/gIQA7MZGvJ story.html.

60 'US Drones' Tech FAQ http://www.tech-faq.com/us-drones.html; Winslow Wheeler, 'The MQ-9's Cost and Performance' Time (28 February 2012) http://nation.time.com/2012/02/28/2-the-mq-9s-cost-and-performance/.

61 'MQ-1B Predator' (US Air Force, 23 September 2015) https://www.af.mil/About-Us/Fact-

Sheets/Display/Article/104469/mq-1b-predator/; 'MQ-9 Reaper' (US Air Force, 23 September 2015)

https://www.af.mil/About-Us/Fact-Sheets/Display/Article/104470/mq-9-reaper/.

${ }^{62}$ Chris Fuller, See it Shoot it: The Secret History of the CIA's Lethal Drone Program (Yale University Press 2017) 10.

${ }^{63}$ Gordon Lubold and Shane Harris, 'Trump Broadens CIA Powers, Allows Deadly Drone Strikes' Wall Street Journal (Washington, 13 March 2017) https://www.wsj.com/articles/trump-gave-cia-power-to-launch-dronestrikes-1489444374.
} 
Obama was designed by John O Brennan while assistant to the President for homeland security and counterterrorism, in collaboration with Leon Panetta, then-head of the CIA, ${ }^{64}$ firmly entrenching it within the secrecy of the intelligence service. The CIA has continually asserted that the 'fact of the existence or non-existence' of the drone programme is classified, though it has been fairly poorly kept. ${ }^{65}$ Instead, there have been indirect references to the fact that alQaida and associated forces have been ' $[\mathrm{u}]$ nder intense pressure in the tribal regions of Pakistan', and that this has in part been through 'targeted strikes ... sometimes using remotely piloted aircraft'. ${ }^{66}$ The realities of the programme have remained firmly hidden.

\section{i. Consent from the government of Pakistan}

Notwithstanding the general secrecy regarding the operation in Pakistan, justifications have been offered in terms of the lawfulness of this and other remote operations. Consent has formed a key plank in the US official discourse, having been repeatedly presented as a basis upon which the resort to remote airstrikes may be rendered lawful. ${ }^{67}$ The other basis for lawfulness which has been given is self-defence, ${ }^{68}$ however examination of the facts emphasises the flimsiness of this argument: though the US has been subject to what may well constitute armed attacks ${ }^{69}$ that have emanated from the Haqqani network ${ }^{70}$ and al-Qaida in Pakistan, ${ }^{71}$ there is very limited evidence of violence reaching the level of an armed attack coming from TTP. Furthermore, the lack of a continuing threat to the US from TTP and al-Qaida in Pakistan reduces the scope for airstrikes against those groups to be classified as necessary. Therefore, consent from the government is the only tenable basis upon which the campaign in Pakistan can be considered as being lawful.

In terms of the general framework for consent to the use of force, the invitation from the government of Pakistan is broadly uncontroversial. Consent was given in 2004 by President

\footnotetext{
${ }^{64}$ Fuller (n 62), 209-10.

${ }^{65}$ Medea Benjamin, Drone Warfare: Killing by Remote Control (Verso 2013) 59.

${ }^{66}$ John O Brennan, 'The Ethics and Efficacy of the President's Counterterrorism Strategy' (Wilson Center, 30

April 2012) http://www.wilsoncenter.org/event/the-efficacy-and-ethics-us-counterterrorism-strategy.

${ }^{67}$ Eric Holder, 'Attorney General Eric Holder Speaks at Northwestern University School of Law' (US

Department of Justice, 5 March 2012) http:/www.justice.gov/opa/speech/attorney-general-eric-holder-speaksnorthwestern-university-school-law; Brennan (n 66); US Department of Justice, Lawfulness for a Lethal Operation Directed Against a US Citizen who is a Senior Operational Leader of al-Qa'ida or an Associated Force (White Paper, 2011) https://fas.org/irp/eprint/doj-lethal.pdf 1.

${ }^{68}$ Koh (n 29); Brennan (n 66).

${ }^{69}$ Armed attacks are necessary before a state can invoke self-defence as a justification for the use of force, per Article 51 of the UN Charter.

${ }^{70}$ For instance the bombing of a CIA base in Kohst Province in 2009: Alissa J Rubin and Mark Mazzetti, 'Suicide Bomber Killed CIA Operatives' New York Times (Kabul, 30 December 2009) https://www.nytimes.com/2009/12/31/world/asia/31khost.html?mtrref=www.google.co.uk (however, elsewhere
} this attack was attributed to TTP. See, for instance, Tom Cohen, 'Taliban Factions Compete for Credit in CIA Bombing Deaths' CNN (Washington, 4 January 2010)

http://edition.cnn.com/2010/US/01/03/cia.bombing.claims/); a siege of the US Embassy and headquarters of NATO in Kabul in 2011: Jack Healy and Alissa J Rubin, 'US Blames Pakistan-Based Group for Attack on Embassy in Kabul' New York Times (Kabul, 14 September 2011)

https://www.nytimes.com/2011/09/15/world/asia/us-blames-kabul-assault-on-pakistan-based-group.html; and an attack on the US consulate in Heart in 2013: Elise Labott and Masoud Popalzai, 'US Consulate in Heart, Afghanistan, Attacked; 3 Reported Dead' CNN (13 September 2013)

https://edition.cnn.com/2013/09/13/world/asia/us-consulate-afghanistan-attack/index.html.

${ }^{71}$ This 'franchise' of al-Qaida is viewed by the US as the 'core' of the group, therefore being responsible for the September 112001 attacks: Rohan Gunaratna and Anders Nielsen, 'Al Qaeda in the Tribal Areas of Pakistan and Beyond' (2008) 31(9) Studies in Conflict and Terrorism 775, 777-8. 
Musharraf, ${ }^{72}$ and subsequently by Prime Minister Raza Gilani. ${ }^{73}$ Indeed, there is some suggestion that Pakistani officials were involved in authorising each strike. ${ }^{74}$ Thus it seems that there is little debate that consent was 'freely given' and not 'vitiated by error, fraud, corruption or coercion' as required under the framework identified above. ${ }^{75}$ Further, as consent came from the highest echelons of the government of Pakistan it is submitted that the requirement that it be given by a person or body with the 'authority to consent' is also satisfied. That President Musharraf took power in 1999 as the result of a military coup, overthrowing the elected prime minister, Nawaz Sharif, ${ }^{76}$ raises questions as to the 'legitimacy' of the administration in terms of the provision of consent. However, practice is insufficient to suggest that there is a need for a government to be democratically elected before it can consent to intervention ${ }^{77}$ and so this does not provide a realistic impediment to consent. Therefore we can conclude fairly comfortably that consent by Pakistan to US intervention was valid.

Despite this, a key feature of Pakistan's consent to US operations is that it was given in secret, coming to public attention only as the result of leaks to the media. Indeed, not only was the issuance of consent kept secret, but the government of Pakistan repeatedly objected to and condemned US drone strikes. President Asif Ali Zardari rejected the suggestion that Pakistan was involved in authorising drone strikes, branding them a 'violation of sovereignty' and 'counter-productive', ${ }^{78}$ sentiment that was also communicated to the UN Human Rights Council. ${ }^{79}$ Later, Pakistan's foreign ministry described US strikes as 'illegal', ${ }^{80}$ and its ambassador to the UK stated that '[n]o one supports drone attacks by the Americans' ${ }^{81}$ Beyond this, leaked cables demonstrate a specific plan to hide the government's consent to the US operations, Prime Minister Gilani having asserted that when a strike was carried out the government would 'protest in the National Assembly and then ignore it' ${ }^{82}$ The exitance of consent was thus veiled and contradicted by the public rhetoric that came with it. This allowed the government of Pakistan to deny to its population that it had invited the US to conduct strikes that were incidentally killing civilians and it allowed the US to maintain relative secrecy as to its operations, reducing the extent to which they could be scrutinised.

The nature of these operations raise the question of whether the secrecy of consent has an impact upon lawfulness, to which this work will now turn. Of course the answer to this question

\footnotetext{
${ }^{72}$ Steve Coll, 'The Unblinking Stare: The Drone War in Pakistan' The New Yorker (24 November 2014)

https://www.newyorker.com/magazine/2014/11/24/unblinking-stare.

73 'Secret Memos "Show Pakistan Endorsed US Drone Strikes"' BBC (24 October 2013)

https://www.bbc.co.uk/news/world-asia-24649840.

${ }^{74}$ Miller and Woodward (n 7).

75 See text to $\mathrm{n} 43$.

${ }^{76}$ Sean D Murphy, 'US Reaction to Military Coup in Pakistan' (2000) 94 American Journal of International Law 354.

77 de Wet (n 33), 989; Fox (n 46), 836-7.

78 Andrew Buncombe, 'President Asif Ali Zardari Replies to Questions from the Independent' The Independent (8 April 2009) https://www.independent.co.uk/news/world/asia/president-asif-ali-zardari-replies-to-questionsfrom-the-independent-1665034.html.

${ }^{79}$ UNHRC, Report of the Working Group on the Universal Periodic Review: Pakistan (26 December 2012) UN Doc A/HRC/22/12 para 15

${ }^{80}$ Qasim Nauman, 'Pakistan condemns U.S. drone strikes' Reuters (Islamabad, 4 June 2012)

https://www.reuters.com/article/us-pakistan-usa-drones/pakistan-condemns-u-s-drone-strikesidUSBRE8530MS20120604.

${ }^{81}$ Tim Lister, 'WikiLeaks: Pakistan Quietly Approved Drone Attacks, U.S. Special Units' CNN (2 December 2010) https://edition.cnn.com/2010/US/12/01/wikileaks.pakistan.drones/index.html.

${ }^{82}$ Rob Crilly, 'Wikileaks: Pakistan Privately Approved Drone Strikes' The Telegraph (Islamabad, 1 December 2010) https://www.telegraph.co.uk/news/worldnews/wikileaks/8172922/Wikileaks-Pakistan-privatelyapproved-drone-strikes.html.
} 
is generally applicable to all uses of force where the reality of consent may be hidden, not just those that might be categorised as liquid warfare, but confluence of factors in the case of US intervention in Pakistan renders the issue particularly stark and pressing.

\section{Publicity and the production of 'valid' consent}

There are clear reasons in favour of a publicity requirement for the production of valid consent. Perhaps most obviously, such a requirement would allow greater transparency and public scrutiny of the extraterritorial uses of force by our governments. Conflict results in people being killed, and so there is a moral imperative in support of encouraging greater oversight. Further, a need to publicise consent could reduce the likelihood that states will engage in forceable intervention which, though it may be considered naïve, is an important aim. Indeed, the absence of a publicity requirement positions the doctrine of consent as a tool that provides remarkable freedom for states to use force that hollows out to a large extent the aim of international peace and security. From a more practical perspective, the lawfulness of an intervention that has been invited is contingent upon it remaining within the parameters and scope of the invitation, ${ }^{83}$ and so making clear the contours of consent will make it more easy to assess whether a state has gone beyond the limits of what has been permitted. Of course there are also arguments against requiring that states must give consent to interventions publicly, no doubt there are operational reasons in support of limiting what information is given about a state's military activities. Further, requiring publicity arguably may be a fetter that is not easily reconciled with the concept of consent as being an exercise of sovereignty. My belief is that it is desirable for there to be a publicity requirement for the reasons given above, and to enable consent to operate as an actual check on uses of force rather than as a legal trump card providing an easy justification for military interventions.

The following section will consider whether there is doctrinal support for asserting a publicity requirement within intervention by invitation, looking first to the law on state responsibility, then to the law on the use of force.

\section{i. Publicity through the framework of state responsibility}

Having identified that state responsibility, while not containing the definitive framework for the use of force with consent, provides at least an indicative general framework of elements required for consent to be valid, it is necessary to consider whether there is anything within that framework that suggests a further requirement of publicity.

The final draft of Article 20 gives no indication as to the manner in which valid consent must be given, however the commentary sets out certain modalities, asserting that consent must be 'clearly established' and 'actually expressed', not 'merely presumed'. ${ }^{84}$ The references to clarity and expression could be argued to imbue the provision of consent with a need for publicity if it is to be valid under the law of state responsibility. To express something is to make it known through words, and to do so 'actually' gives the impression of a process that is objectively verifiable. Similarly, the requirement that consent is 'clearly established' can be read to set out an imperative that consent is apparent (clear), rather than being hidden (unclear), suggesting transparency and a lack of obscurity.

\footnotetext{
${ }^{83}$ DASR, Article 20, para 9.

${ }^{84}$ DASR, Article 20, para 6.
} 
However, the debates surrounding the adoption of Article 20 do not provide support for these literal interpretations of the modalities of consent. There was only ever very limited support within the ILC for the exclusion of consent where it is given implicitly, and only in 'grave cases where there was a possibility of abuse', such as the request for military support for a colonial regime. ${ }^{85}$ During the 1979 drafting meetings, the Special Rapporteur asserted that "the possibility of implicit consent should not be entirely ruled out, since the conduct of a State sometimes constituted evidence of consent implicitly given'. ${ }^{86}$ The subsequent draft Articles and commentary couched 'valid' expression and the 'clear' establishment of consent very much in terms of it being the true reflection of the will of a state, rather than in terms of any specific modality. The commentary proclaimed that " $[\mathrm{n}] \mathrm{o}$ special condition as to form is required for its expression; like all manifestations of the will of a State, such consent can be expressed or tacit, explicit or implicit, provided, however, that it is clearly established. ${ }^{87}$ Thus expression and clarity were not conceived of in such a way as to create a requirement of form in terms of consent, but rather to distinguish valid consent, which was in actuality the will of a state, from presumed consent, which was not. Presumed consent was held to denote a situation in which one state believed that another would consent to an act, but where there had in fact been no actual consent. ${ }^{88}$ This differs from tacit consent, in which conduct demonstrates one state's implicit (though nonetheless real) acquiescence to an agreement. ${ }^{89}$

The nature and form of consent within state responsibility remained somewhat vague later on in the drafting process, with the need for consent to be 'validly given' being criticised for a lack of clarity. ${ }^{90}$ Indeed, such was the perceived vagueness that James Crawford, then-Special Rapporteur, favoured the removal of consent altogether from the draft articles. ${ }^{91}$ The inclusion of validity was seen as problematic as it implied that consent requires 'certain modalities' without providing specifics..$^{92}$ Ultimately, these modalities were viewed as dependent on the relevant primary rule for a given instance of consent rather than being something that could be present generally through state responsibility. ${ }^{93}$

On this basis, the framework of consent within state responsibility cannot be said to provide for any kind of publicity requirement. Though words like 'expressed' and 'clearly' can be read to imply conduct or words that publicise consent this is far from the only plausible interpretation. Furthermore, they were not intended to include this meaning. The key determinant of validity is that consent, in whatever form it is presented, reflects the true intention of a state to exercise its sovereignty and agree to an act that would otherwise be wrongful.

\footnotetext{
${ }^{85}$ Only SP Jagota, ILC member for India argued against the possibility of implicit consent: ILC (n 36), 37.

${ }^{86} 1543^{\text {rd }}$ Meeting (31 May 1979) (1979) Yearbook of the International Law Commission, vol I, 52.

${ }^{87}$ Eighth Report on State Responsibility by My Roberto Ago, Special Rapporteur (1979) Yearbook of the International Law Commission, vol II(1) para 69.

${ }^{88}$ Ibid, para 69.

${ }^{89}$ The example given is the Russian Indemnity case before the Permanent Court of Arbitration, in which Russia was held to have consented to the non-payment of moratory interest owed by Turkey, by virtue of conduct demonstrating that it was proceeding on that basis (that is, accepting periodical payments without interest): Ibid, para 69. See also, Document A/34/10, Report of the International Law Commission on the Work of its ThirtyFirst Session (1979) Yearbook of the International Law Commission, vol. II(2) 112-3

${ }^{90}$ Comments and Observations Received by Governments (1998) UN Doc A/CN.4/488, 80 (France).

${ }^{91}$ Crawford (n 42), para 237.

92 Ibid, para 242.

${ }^{93}$ Ibid.
} 


\section{ii. Publicity through the primary rules on the use of force}

As the secondary rules of state responsibility are unable to provide a basis upon which to ground a requirement of publicity for consent to the use of force, it is necessary to consider whether one can be found within relevant primary rules.

There has been limited scholarly argument in favour of a publicity requirement for the use of force. Where it is discussed, the emphasis is not on there being an obligation to make consent public but rather on the difficulties faced by a state in evidencing that valid consent has been given where it has been kept hidden. In discussing the lack of 'express, public consent' for US operations in Pakistan, Mary Ellen O'Connell has stated not that there is an intrinsic need for publicity, but that if consent is secret the US 'would have difficulty proving in a court or other public fora' that valid consent exists. ${ }^{94}$ Sean Murphy has likewise couched the issue of publicity in terms of evidence, having asserted that an absence of public consent does not equate to an absence of consent per se, and that the key is the ability to produce evidence of consent 'in whatever venue necessary'. ${ }^{95}$ This is also the approach of the International Law Association (ILA) Use of Force Committee, which has been explicit that 'consent could potentially be valid whether it is given publicly or in private,' and that 'the key issue is likely to be whether the consent can be evidenced. ${ }^{96}$ Particularly relevant to this work is the Committee's assertion that where consent is given in secret but is contradicted in public, consent is not vitiated but its existence becomes 'a matter for evidentiary proceedings for determination of the said consent. ${ }^{97}$ This chimes with the acceptance of tacit consent within state responsibility, in that though consent has not been explicitly made public it can nonetheless be evidenced if necessary.

The 2011 IDI resolution on military assistance on request provides an enunciation of consent that is specific to the use of force. The resolution bears similarities with the DASR, referring to a need for a 'valid' request, ${ }^{98}$ which must 'reflect[] the free expression of will of the requesting State and its consent to the terms and modalities of the military assistance. ${ }^{99}$ Nevertheless, it is also narrower than the DASR: a 'request' is a positive act, arguably auguring away from implicit or tacit consent. Further, the resolution also requires ad hoc consent to be given where military assistance is based on a pre-existing treaty, ${ }^{100}$ suggesting stricter parameters for consent to the use of force. Nevertheless, the potentially more positive and explicit modalities of consent under the resolution cannot realistically be read to imply such a requirement (or prohibition) into it.

The closest the resolution gets to setting out a specific publicity requirement is with its imperative that '[a]ny request that is followed by military assistance shall be notified to the Secretary-General of the United Nations. ${ }^{101}$ This replicates the mandatory wording of the

\footnotetext{
${ }^{94}$ Mary Ellen O’Connell, 'Unlawful Killing with Combat Drones: A Case Study of Pakistan, 2004-2009' in Simon Bronitt, Miriam Gani and Saskia Hufnagel (eds), Shooting to Kill: Socio-Legal Perspectives on the Use of Lethal Force (Hart 2012) 282 (emphasis added).

${ }^{95}$ Sean D Murphy, 'The International Legality of US Military Cross-Border Operations from Afghanistan into Pakistan' (2009) 85 International Legal Studies 109, 118.

${ }^{96}$ ILA (n 38), 613 (emphasis added).

${ }^{97}$ Ibid.

${ }^{98}$ IDI Res 2011 Art 4(2).

99 IDI Res 2011 Art 1(b).

${ }^{100}$ IDI Res 2011 Art 4(3).

${ }^{101}$ IDI Res 2011 Art 4(4).
} 
reporting requirement of Article 51 of the UN Charter. ${ }^{102}$ Though there is, of course, a significant difference in the legal force of the Charter and the IDI resolution, it is illustrative to consider the obligations under each, especially given that the resolution is purportedly based on state practice. The Article 51 reporting requirement is interesting as, though clearly an imperative under the Charter, a failure to report does not render otherwise lawful self-defence unlawful. ${ }^{103}$ Instead, failure to report has been suggested to indicate that the defending state 'does not believe in the genuineness of its action', and therefore may undermine the legitimacy of its claim to lawful self-defence. ${ }^{104}$ It seems likely that the impact of a failure to report an intervention by invitation is similarly not dispositive of the lawfulness of the intervention; indeed, during its 1957 intervention in Oman, at the request of the Sultan of Muscat, the United Kingdom (UK) government indicated that the invitation did not oblige it to inform the UN of the military operation. ${ }^{105}$ Beyond substantive lawfulness, Green has highlighted that the reporting requirement of Article 51 has 'a more general function of "publicizing" a claim of self-defence to the world at large. ${ }^{\prime 06}$ The need to report on uses of force fosters transparency, enabling objective assessment of actions undertaken by states. This is perhaps more likely the intended purpose of the IDI reporting requirement, having a primarily political rather than legal function.

Considering these two frameworks, there are apparently no strong legal arguments to support there being a requirement to publicise the existence of consent to the use of force. There are certainly good policy arguments in favour, and it can be said that there is an evidentiary benefit that provides an indirect legal reason for the finding of a publicity requirement, but the lex lata betrays no reasonable basis upon which to identify one. This is not, however, the end of the search and the next section will consider a selection of state practice to see whether it is possible to discern any kind of pattern indicating a publicity requirement.

\section{iii. Publicity and the practice of states}

Considering the practice of states, and the manner in which interventions have been consented to historically, it is possible to discern patterns and draw conclusions on the question of publicity. It should be emphasised that it is not claimed that this work contains a definitive account of the customary nature of consent, it is instead an engagement with examples in order to provide an overview of dominant practices and so inform our understanding of potential emergent norms relating to publicity.

A number of patterns emerge from the examination of state practice. First, in the vast majority of examples analysed, consent was in some way publicised: of 19 instances of consensual intervention examined, consent was publicised in $17 .{ }^{107}$ This is significant as it suggests a

\footnotetext{
102 'Measures taken by Members in the exercise of this right of self-defence shall be immediately reported to the Security Council'.

103 James A Green, 'Article 51 Reporting for Self-Defense Actions' (2015) 55(3) Virginia Journal of International Law 563, 595; Nicaragua (n 34), para 235.

${ }^{104}$ Green (n 103). Indeed, the ICJ in the Nicaragua case observed that while failure to report self-defence did not render the use of force by the US unlawful, it did undermine the avowed claim of that state to be responding to an armed attack: Nicaragua (n 34), para 235.

105 HL Deb, 25 June 1957, vol 205, cols 129-30.

106 Green (n 103), 569.

107 These are: the UK in Greece (from 1944); Australian support for the UK during the Malayan Emergency (1948); the UK in Oman (1957); the UK in Jordan (1958); the US in Lebanon (1958); the Soviet Union in Hungary (1956); Belgium in Congo (1960 and 1964); France in Cameroon (from 1960); France in Chad (on three occasions, 1960, 1983 and 2019); France in Gabon (from 1960); the Soviet Union in Czechoslovakia
} 
strong tendency to make public the fact that consent has been given for an intervention, which is understandable given the power of consent to provide legitimacy (both legal and political) to an intervention. Nevertheless, the manner in which consent has been publicly asserted has varied considerably between different interventions. In many examples, publication came after an intervention began, sometimes as a reaction to other states' suggestions that intervention was unlawful. The diversity of practice leads to the conclusion that there is no specific approach to publicity that could be considered as having generated a requirement of publication for consent to be valid, undermining the idea that there might be an obligation upon states to publicise consent for an intervention to be lawful.

Consent was publicised before organs of the UN in 10 of the interventions considered here, representing the most common form of publication. Proactive assertion that consent formed the basis of an intervention (that is, assertions unprompted by other states), in letters to the UNSC or UN General Assembly (UNGA), is perhaps the clearest example of publication. This practice is seemingly reflective of the imperative within the IDI resolution that the UN Secretary General should be notified of military intervention upon request. This appears to have been the case with Belgium's 1964 intervention in Congo to rescue its nationals, which was expressed, in a letter sent to the UNSC in advance of the operation, as occurring 'in consultation with the Congolese Government and at its request'. ${ }^{108}$ On other occasions, states have sent similar letters to the UNSC soon after an intervention has begun. For instance, the Soviet Union informed the UNSC that its intervention in Czechoslovakia was carried out 'pursuant to a request by the Government of that State' on 21 August 1968, the day after the intervention began. ${ }^{109}$ More recently, this was the approach taken by France in its 2013 intervention in Mali: France's letter, sent hours after the intervention started, asserted that it had 'responded ... to a request for assistance from the Interim President of the Republic of Mali'. ${ }^{110}$

Providing similarly clear examples of publication, there have been several instances of consent being explicitly asserted as the basis for intervention during meetings of the UNSC, which in some cases came in advance of the start of intervention. In 1956, the representative of the Soviet Union asserted at a meeting of the UNSC that it had been requested by the Hungarian government to intervene, which it then did two days later. ${ }^{111}$ Providing even more notice, in 1983 the French representative to the UNSC confirmed that the government of Chad had requested military assistance in response to incursion by Libyan forces and that it was acting upon the request. ${ }^{112}$ While French troops entered Chad shortly after the request was publicised, ${ }^{113}$ force was not used until several months later, in response to an attack by Libyan troops against French planes. ${ }^{114}$

(1968); the US in Yemen (from 2001); the US in Somalia (from 2003); France in Mali (2013); Russia in Ukraine (2014); and ECOWAS in the Gambia (2016).

${ }^{108}$ UNSC, Letter dated 21 November 1964 from the Permanent Representative of Belgium to the President of the Security Council (22 November 1964) UN Doc S/6055.

${ }^{109}$ UNSC, Letter dated 21 August 1968 from the Permanent Representative of the Union of Soviet Socialist Republics Addressed to the President of the Security Council (21 August 1968) UN Doc S/8759.

${ }^{110}$ UNSC, Identical letters dated 11 January 2013 from the Permanent Representative of France to the United Nations addressed to the Secretary-General and the President of the Security Council (14 January 2013) UN Doc S/2013/17.

${ }^{111}$ UNSC, 752 ${ }^{\text {nd }}$ meeting (2 November 1956) UN Doc S/PV.752 para 136.

112 UNSC, $2465^{\text {th }}$ meeting (12 August 1983) UN Doc S/PV.2465 paras 134-5.

113 'French Confirm Troop Build-Up' The Times (16 August 1983).

${ }^{114}$ Diana Geddes, 'French Pilot Killed as Chad Rebels Down Jet' The Times (Paris, 26 January 1984). 
Other states have used meetings of the UNSC to publicise the existence of consent at the point of intervention or soon after it, as did the US when it entered Lebanon in 1958 at the request of the Lebanese government. ${ }^{115}$ When the UK intervened in Jordan in 1958, the existence of consent was communicated by the representative of Jordan and confirmed by the UK as being the basis of intervention during a meeting of the UNSC on the day the intervention began. ${ }^{116}$ Belgium's 1960 intervention in Congo, reputedly in order to protect several hundred Europeans, was publicly declared by the representative of Belgium to be undertaken 'with the full agreement of the head of the provincial government' ${ }^{117}$ at a meeting of the UNSC three days after it began, although the existence of the consent of the Congolese Foreign Minister as well as that of the Prime Minister of the province had appeared in the press as the intervention began. ${ }^{118}$ Despite its additional controversy, ${ }^{119}$ the same can also be said for Russian intervention in Ukraine in 2014, in which the request for military intervention, in the form of a letter from ousted President Yanukovich, was publicised during the $7125^{\text {th }}$ meeting of the UNSC by the representative of the Russian Federation, two days after the intervention began. ${ }^{120}$

In other instances, consent has been publicised before the UNSC though in a less explicit manner. An example is the case of the ECOWAS intervention in The Gambia to support the newly elected president Adama Barrow. During his inauguration, Barrow appealed to 'ECOWAS, AU, and the UN, particularly the Security Council, to support the government and people of the Gambia in enforcing their will', and this was followed by intervention by Senegalese and Nigerian troops later the same day. ${ }^{121}$ The request for support from Adama Barrow was proclaimed by the representative of Senegal in the UNSC debate on the situation in The Gambia. ${ }^{122}$ Nevertheless, this was not explicitly related to the use of force, and indeed the debate saw many states emphasise the need to avoid force in resolving the situation; ${ }^{123}$ therefore the reference by Senegal to consent from the government of The Gambia can only be seen as, at most, implicitly publicising consent to the use of force before the UNSC.

Additionally, there are examples of consent being publicised within meetings of the UNSC reactively, in response to accusations that a use of force was, or may have been, unlawful. In such cases the publication cannot really be seen as supporting any kind of general obligation to publicise, but rather as a function of the power of state consent to legitimise an intervention. An early example of this is the UK's presence in Greece from 1944. Given that the intervention began before the birth of the UN it is unsurprising that it was not reported at the time; nevertheless, Greek consent was not publicised by the UK at the international level at all until the lawfulness of the ongoing intervention was challenged by the Soviet Union. ${ }^{124}$ Similarly, the UK did not publicise before the UN the existence of consent from the Sultan of Muscat and

\footnotetext{
${ }^{115}$ UNSC, $827^{\text {th }}$ meeting (15 July 1958) UN Doc S/PV.827 para 34.

${ }^{116}$ UNSC, 831 ${ }^{\text {st }}$ meeting (17 July 1958) UN Doc S/PV.831 paras 24 (Jordan) and 28 (UK). It is noteworthy that while the representative of Jordan couched this invitation in terms of collective self-defence under Article 51, the UK referred to it in terms emphasising consent (paras 29-30).

${ }^{117}$ UNSC, 873 ${ }^{\text {rd }}$ meeting (13 and 14 July 1960) UN Doc S/PV.873 para 186.

118 'Belgian Troops Fly to Aid Elisabethville Europeans' The Times (Brussels, 10 July 1960).

${ }^{119}$ See, for instance, Olivier Corten, 'The Russian Intervetnion in the Ukrainian Crisis: Was Jus Contra Bellum

“Confirmed Rather than Weakened"?' (2015) 2(1) Journal on the Use of Forces and International Law 17.

${ }^{120}$ UNSC, $7125^{\text {th }}$ meeting (15 July 1958) UN Doc S/PV.7125, 3-4.

${ }^{121}$ Ruth Maclean, 'Troops Enter the Gambia After Adama Barrow in Inaugurated in Senegal' The Guardian

(Banjul, 19 January 2017) https://www.theguardian.com/world/2017/jan/19/new-gambian-leader-adama-

barrow-sworn-in-at-ceremony-in-senegal.

${ }^{122}$ UNSC, $7866^{\text {th }}$ meeting (19 January 2017) UN Doc S/PV.7866, 2.

${ }^{123}$ Ibid, 2-3 (Uruguay); 3 (Bolivia); 4 (Kazakhstan); 5 (US).

${ }^{124}$ UNSC, $6^{\text {th }}$ meeting (1 February 1946) UN Doc S/PV.6.
} 
Oman to its intervention in Oman until the lawfulness of the operation was challenged, ${ }^{125}$ at which point it presented the Sultan's request verbatim before the UNSC. ${ }^{126}$ While being examples of publication per se, these cannot be seen as providing support for the obligatory publication of consent for it to be deemed 'valid'. Instead they reflect the evidentiary approach favoured by the ILA, in which the key factor for validity is not publication at the time of an intervention, but whether it can be evidenced afterwards.

Despite not being presented before the UNSC or UNGA as they began, neither of the above interventions by the UK were secret. Both were examples of a further way in which the consensual basis for interventions has been publicised: publication through public parliamentary debate. It was made clear in a parliamentary debate on 19 December 1944 that British forces were present in Greece at the 'express invitation' of the Greek Government, ${ }^{127}$ although this was over a month after troops had arrived, and 11 days after they were reputed to have killed 28 civilians during a demonstration. ${ }^{128}$ In the case of the British intervention in Oman, the existence of the Sultan of Muscat and Oman's request was presented to Parliament on 22 July 1957, around two days after the intervention began, ${ }^{129}$ with the full text of the letter requesting assistance being publicised on 29 July. ${ }^{130}$ A further example is Australia's intervention at the request of the UK during the Malayan Emergency, which was not presented before any UN body, but was debated before the Australian parliament. ${ }^{131}$ It is questionable to what extent this can be viewed as publicising, given that the statement came in response to a question on Australia's support of the British government generally, rather than as an unsolicited act making clear the basis of Australia's intervention. Further, the statement was somewhat vague, asserting simply that '[c]ertain requests have been made by the British Government for assistance in preserving law and order in Malaya'. ${ }^{132}$ It could even be argued that, as the request was described simply as 'certain requests', there is an element of secrecy, or at least opacity. Nevertheless, where consent comes to light during parliamentary debates, this can be seen as a form of publication as a product of the functioning of one branch of a state's government, scrutinising the executive. Though the mention of consent in such a forum, which is then incidentally published - in that it appears within the parliament's record-is hardly the same as active publication within an international forum, it remains a form of published consent.

Finally, there are a number of examples of interventions in which the invitation was seemingly made public solely through the news media. These represent weaker examples of publication than those described above, involving less active engagement from either consenting or intervening state in the act of publicising, yet they are nonetheless not instances of secret consent. Examples include various interventions by France acting as the 'Gendarme of Africa' ${ }^{133}$ in its ex-colonies, with which it had agreed an array of defence agreements and

\footnotetext{
${ }^{125}$ UNSC, Letter dated 13 August 1957 from the permanent representatives of Egypt, Iraq, Jordan, Lebanon, Libya, Morocco, Saudi Arabia, Sudan. Syria and Yemen Addressed to the President of the Security Council (15 August 1957) UN Doc S/3865.

${ }^{126}$ UNSC, $783^{\text {rd }}$ meeting (20 August 1957) UN Doc S/PV.783 para 48.

${ }^{127}$ HL Deb 19 December 1944, vol 134, col 411.

${ }^{128}$ Ed Vulliamy and Helena Smith, 'Athens 1944: Britain's Dirty Secret' The Guardian (20 November 2014). See also André Gerolymatos, An International Civil War: Greece, 1943-1949 (Yale University Press 2004).

${ }^{129}$ HC Deb 22 July 1957, vol 574, col 32.

${ }^{130}$ HC Deb 29 July 1957, vol 574, cols 871-72; HL Deb 29 July 1957, vol 205, cold 242-43.

${ }^{131}$ House Hansard (Australia), no 36, 1948 (2 September 1948) 31.

132 Ibid (emphasis added).

${ }^{133}$ Victor-Manuel Vallin, 'France as the Gendarme of Africa, 1960-2014' (2015) 130(1) Political Science Quarterly 79.
} 
military technical assistance agreements. ${ }^{134}$ These agreements, which in some cases were themselves secret, ${ }^{135}$ have been posited as the basis for France's various interventions in postcolonial Africa, but seemingly always in addition to ad hoc consent. ${ }^{136}$ Immediately postindependence, in 1960, France intervened in Cameroon to combat the Union of the Peoples of Cameroon (UPC) at the request of President Ahidjo. ${ }^{137}$ The defence agreement forming the basis of this intervention was secret, ${ }^{138}$ however the existence of the President of Cameroon's ad hoc consent was publicised in the media at the time, ${ }^{139}$ demonstrating that the consent itself was not secret. Likewise, French intervention in Chad against the National Liberation Front of Chad (FROLINAT) was based on a defence agreement which was ostensibly public, though it contained a secret clause relating to the use of French forces for the maintenance of internal order. ${ }^{140}$ As with the case of Cameroon, despite the secrecy surrounding aspects of the defence agreement, consent to the intervention from President Tombalbaye featured in contemporary news reports. ${ }^{141}$ In a further example, France intervened in Gabon at the ostensible ${ }^{142}$ request of vice-President Yembit when President M'Ba was kidnapped during an attempted coup. Again, though this consent was not broadcast to the international community, it was reported in the news a day after the intervention that consent had been given. ${ }^{143}$

Much more recently, France intervened in Chad in February 2019, carrying out airstrikes against a convoy of fighters leaving Libya. Though French troops and aircraft are present in the Sahel under the ongoing Operation Barkhane ${ }^{144}$ this use of force was specifically requested by the government of Chad, and reported in the media. ${ }^{145}$ Similarly, the US counter-terrorism programmes in Yemen and Somalia have both been asserted publicly to have the consent of each government, though again this has been through news media. In Yemen, consent was revealed by President Hadi during a 2012 interview with the Washington Post, 10 years after the US began interventions in that country. ${ }^{146}$ In Somalia, consent was first publicised in 2009 by interim President Yusuf, ${ }^{147}$ two years after the start of the operation, and reiterated in 2011 by Somalia's defence minister. ${ }^{148}$ These operations contrast with others in that publication

${ }^{134}$ Robin Luckham, 'French Militarism in Africa' (1982) 24 Review of African Political Economy 55, 57.

${ }^{135}$ Diana Haag, 'Mechanisms of Neo-Colonialism: Current French and British Influence in Cameroon and Ghana' (2011) Institut Català Internacional per la Pau, ICIP Working Papers 2011/6, 26; Ibid, 58.

${ }^{136}$ Guy Martin, 'Continuity and Change in Franco-African Relations' (1995) 33(1) Journal of Modern African Studies 1, 13.

${ }^{137}$ Elizabeth Schmidt, Foreign Intervention in Africa: From the Cold War to the War on Terror (Cambridge University Press 2013) 182.

${ }^{138}$ Luckham (n 134), 58.

${ }^{139}$ Helen Kitchen, 'Cameroun Faces Troubled Future' (1960) 5(1) Africa Special Report 1, 2.

${ }^{140}$ Nathaniel K Powell, “"Experts in Decolonization?” French Statebuilding and Counterinsurgency in Chad, 1969-1972' (2020) 42(2) International History Review 318, 321.

${ }^{141}$ See, for instance, 'French Troops Fly to Crush Chad Rebellion' The Times (29 August 1968).

${ }^{142}$ Ostensible in that the request was written by Jacques Foccart (adviser to Presdent de Gaulle and director of the cabinet in charge of African affairs) and signed by President de Gaulle before being signed by vice-President Yembit: Vallin (n 133), 81.

143 'French Troops Crush Gabon Revolt' The Times (London, 20 February 1964).

${ }^{144}$ Flore Berger, 'West Africa: Shifting Strategies in the Sahel' (International Institute for Strategic Studies, 1 October 2019)

145 'French Air Strikes Target Convoy Entering Chad from Libya' France 24 (4 February 2019)

https://www.france24.com/en/20190204-france-chad-air-strikes-convoy-libya.

${ }^{146}$ Greg Miller, 'Yemeni president acknowledges approving U.S. drone strikes' Washington Post (29 September 2012) https://www.washingtonpost.com/world/national-security/yemeni-president-acknowledges-approving-usdrone-strikes/2012/09/29/09bec2ae-0a56-11e2-afff-d6c7f20a83bf story.html.

147 'US Somali Airstrikes Kill Many’ BBC (9 January 2009)

http://news.bbc.co.uk/1/hi/world/africa/6243459.stm.

148 Robert Young Pelton, 'Enter the Drones' (Somalia Report, 7 June 2011)

http://piracyreport.com/index.php/writer/139/Robert Young Pelton. 
came long after the commencement of the interventions, which raises questions as to the extent to which these truly represent examples of publicised rather than secret consent.

Finally, there have been instances of unquestionably secret consent, though these are less prevalent. In addition to the US intervention in Yemen and Somalia, before consent to those interventions was publicised in the media, and its intervention in Pakistan that forms the key focus of this work, the US bombing campaign in Laos between 1964 and 1973 presents an example of secret consent. This intervention, in which 2,000,000 tons of explosives were dropped, was undertaken as part of both the Vietnam War and the civil war within Laos and followed several years of CIA involvement in Laos. ${ }^{149}$ The bombing was carried out with the 'tacit consent' of Prime Minister Souvanna Phouma, ${ }^{150}$ but was kept secret the entire time, from US Congress as well as the international community, in order to give the appearance that the US was abiding by the International Agreement on the Neutrality of Laos. ${ }^{151}$

Ultimately, there are myriad ways in which consent to interventions has been publicised, and while patterns have emerged, there is insufficiently uniform practice to suggest the emergence of a rule that could be said to impose an obligation to make consent to the use of force public. While the proactive publicising of consent before UN bodies might contribute to the development of such a rule, there has clearly been extensive practice in which publication was reactive, coming either after an intervention has begun or in response to criticism. The reactive publication of consent arguably emphasises that consent is valid where it can be demonstrated through the provision of evidence, which would support the validity of secret consent. Further, publication within the media, though useful from an evidentiary perspective, serves in the instances above to demonstrate states failing to publicise consent at an international level, further emphasising the lack of practice in favour of a rule of publicity. Finally, though covert practice is controversial in terms of the extent to which it can support the formation of customary law, ${ }^{152}$ instances of secret consent have occurred in sufficient numbers to further undermine the existence of a rule of publicity. The secrecy of consent seems to reflect the politically controversial nature of such interventions and the potential fragile position of the consenting government (this is arguably the case in the interventions of both Laos and Pakistan), but does not impact upon the validity of consent.

While publicity is the most common approach to consent, and secrecy the exception, there is insufficiently coherent practice to convincingly suggest that a rule requiring publicity has emerged, in part due to the various ways in which the existence of consent has been publicised. As a result, the fact that consent to US airstrikes in Pakistan was given in secret does not impact on the lawfulness of the campaign in terms of the use of force.

\section{Secret consent, liquid warfare and neo-colonial uses of force}

\footnotetext{
${ }^{149}$ Seth Jacobs, The Universe Unravelling : American Foreign Policy in Cold War Laos (Cornell University Press 2012) 170.

${ }^{150}$ Alfred W McCoy, 'America's Secret War in Laos, 1955-75' in Marilyn B Young and Robert Buzzanco (eds), A Companion to the Vietnam War (Blackwell 2002) 292.

${ }^{151}$ Ibid, 293.

152 ILA Committee on the Formation of Customary (General) International Law, London Conference, 15; cf ILC, Report of the International Law Commission, seventieth session (30 April-1 June and 2 July-10 August 2018) UN Doc A/73/10 133.
} 
That consent to military intervention may be given and acted upon in secret emphasises its ontological foundation as an exercise of sovereignty; the decision to invite intervention sits within the purview of a government as the arbiter of a state's domestic jurisdiction. The modalities surrounding the validity of consent therefore focus on the extent to which the state giving consent is technically capable of doing so (insofar as satisfying the requirement of being given by a 'legitimate' government), rather than the manner in which it is given. In this way, it is perhaps more accurate to think of intervention by invitation as a political rather than legal act - it serves to remove an intervention from the legal framework governing the use of force. As a result, consent to the use of force represents the perfect basis for rendering lawful the type of conflict epitomised by liquid warfare which, as discussed above, is characterised by partnerships between territorial and intervening states. Unlike self-defence it need not (legally) be announced, providing a basis upon which for states to engage in covert, mobile, and fluid interventions, which can be presented, if necessary, as lawful by producing the evidence of consent at a later date.

Drawing on Gina Heathcote's feminist critique of inter-state self-defence as grounded in the analogy of interpersonal self-defence, ${ }^{153}$ the concept of consent reflects the language and laws of interpersonal consent, ${ }^{154}$ presupposing a masculine legal subjectivity that 'lends itself to the influence of powerful states'. ${ }^{155}$ As with self-defence, through the operation of consent, states as legal subjects 'are deemed equal so that inequalities between parties are not perceived to impact on the capacity of a state'. ${ }^{156}$ Consent thus obscures power imbalances between states, particularly in situations where one state has limited territorial control. While this is a problematic aspect of consent to the use of force generally, the availability of secret consent makes the problem more acute by further obscuring the workings of power, and strengthening the basis upon which strong states may project force extraterritorially with the imprimatur of lawfulness.

Accordingly, consent should not be viewed as a legal barrier to the use of force in the manner of the various rules within jus ad bellum. Rather than a limitation, consent is an enabler of the use of force. It is true that consent theoretically protects states from unwanted interventionsin which circumstances recourse to the rules of jus ad bellum would be necessary-but it also provides powerful states with a formidable tool to conduct military interventions against nonstate actors, that can be subsequently presented as 'perfectly' lawful. ${ }^{157}$ The doctrine of consent, in justifying the use of force, is therefore susceptible to the criticism (originally levelled against self-defence) that it 'constructs a status quo that contributes to, rather than diminishes, the level of conflict globally. ${ }^{158}$ With no requirement of publicity, consent to the use of force has the potential to do exactly that. It is a doctrine that provides powerful states with incredible latitude to use force with the confidence that this use can comfortably be

\footnotetext{
${ }^{153}$ Gina Heathcote, The Law on the Use of Force: A Feminist Analysis (Routledge 2012) 79-80.

154 This is a topic that begs future exploration but for which there is insufficient space and time to go into in depth presently.

${ }^{155}$ Heathcote (n 153), 88.

${ }^{156} \mathrm{Ibid}, 88$.

157 This refers to the invocation of consent by then-Prime Minister of Australia, Tony Abbott who described any intervention with consent as being 'perfectly perfectly legal under international law': Latika Bourke, 'Tony Abbott Leaves Door Open to Military Action Against Islamic State in Syria' The Sydney Morning Herald (16 September 2014) https://www.smh.com.au/politics/federal/tony-abbott-leaves-door-open-to-military-actionagainst-islamic-state-in-syria-20140916-10hh62.html.

${ }^{158}$ Gina Heathcote, 'Feminist Perspectives on the Law on the Use of Force' in Marc Weller (ed) The Oxford Handbook on the Use of Force in International Law (Oxford University Press 2015) 125.
} 
declared lawful at a later stage. In so doing, the ethical and political implications of these interventions are side-lined, feeding a growing militarism. ${ }^{159}$

While seemingly capable of legitimising any type of intervention, the freedom, covertness and fluidity enabled by secret consent appears to engender the use of a particular type of aerial force, involving long-term, low-level bombing that has clear parallels with tactics adopted by colonial powers. The extensive use of airstrikes within liquid warfare operations, such as the US drone campaign in Pakistan, recalls practices developed by the UK to exert control over its colonial territories. ${ }^{160}$ Dubbed 'air control', these practices involved using aerial surveillance and attack capabilities to pacify 'recalcitrant' tribes in Iraq during the interwar period, ${ }^{161}$ effectively utilising the military in a policing role. Using the air force in this way enabled the "possibility of "radiating" British power throughout the country from a handful of fittingly Spartan bases', ${ }^{162}$ in precisely the same way that the US can radiate power from its own bases around the world. The fluid use of remote technology in an extended programme of airstrikes represents the radiation of military power into the region of North Waziristan in a manner that is risk-free to US personnel, ${ }^{163}$ focusing on security and surveillance, and seeking to effect a political change within the communities targeted. ${ }^{164}$ In a further, human, parallel, the lived experience of communities subjected to long-term drone operations mirrors that of communities subjected to imperial policing through air control in the inter-war period, with impacts upon daily life that replicate the psychological repercussions of air control on citizens in colonised states. ${ }^{165}$ Importantly, these parallels between US liquid warfare and British colonial air control are not spurious-British air control in Iraq has been specifically highlighted as providing methods for effective modern operations. ${ }^{166}$

Considering US operations in Pakistan (and, indeed, elsewhere) the use of secret consent has been integral to the application of these methods and this is likely to continue given the proliferation of liquid warfare as a mode of conflict. ${ }^{167}$ As Priya Satia argues, 'drone policing depends on active secrecy, to stifle whatever trickle of critical opinion continues to emanate from the press at home, as much as abroad. ${ }^{168}$ The absence of a publicity requirement therefore makes the doctrine of consent pivotal to the functioning of this type of neo-colonial projection of power, protecting both the intervening and territorial state from political fallout. In Pakistan, the use of drones by the US was subject to extensive domestic protest, with the Senate and

\footnotetext{
159 Gregory (n 20), 247.

160 Priya Satia, 'Drones: A History From the British Middle East' (2014) 5(1) Humanity: An International Journal of Human Rights, Humanitarianism, and Development 1, 14-5.

161 Priya Satia, 'The Defense of Inhumanity: Air Control and the British Idea of Arabia' (2006) 111(1) American Historical Review 16, 34. See also, Tim R Moreman, "'Small Wars" and "Imperial Policing": The British Army and the Theory and Practice of Colonial Warfare in the British Empire, 1919-1939' (1996) 19)4 Journal of Strategic Studies 105.

162 Satia (n 161), 28.

${ }^{163}$ Leaving aside the evidence that drone warfare may have significant psychological impacts on pilots: Matthew S Lowe and James T Gire, 'In the Mind of the Predator: The Possibility of Psychological Distress in the Drone Pilot Community’ (2012) 17(2) Modern Psychological Studies 2.

${ }^{164}$ Mark Neocleous, 'Air Power as Police Power' (2013) 31(4) Environment and Planning D: Society and Space 578, 582-4.

165 Alex Edney-Brown, 'The Psychological Effects of Drone Violence: Social Isolation, Self-Objectification, and Depoliticization' (2019) Political Psychology, 12-3.

166 Neocleous (n 164), 580.

${ }^{167}$ Michael T Kare, 'In Trump's Cruise-Missile Diplomacy, Iran and North Korea Could be Next' The Nation (11 April 2017) https://www.thenation.com/article/in-trumps-cruise-missile-diplomacy-iran-and-north-koreacould-be-next/

${ }^{168}$ Satia (n 160), 8.
} 
National Assembly jointly condemning the operations as unlawful and a violation of sovereignty; ${ }^{169}$ in such a politically fragile situation it would seem that consent could not operate other than through secrecy. The doctrine of consent represents an aggregation of sovereignty within the executive and this aggregation is deeply entrenched by the validity of secret consent, veiling the decision to invite military intervention from public and political scrutiny. ${ }^{170}$

Once again, the doctrine is revealed to be imbricated within these practices, enabling military intervention and conflicting with the notion that it acts as a limitation on the use of force. Instead consent simply offers a cover, providing a sweeping legitimation of the extraterritorial use of force, which can be held out to be lawful, with all the rhetorical power that comes with such a designation. It is a legal tool that is firmly geared towards the entrenchment of hegemony.

\section{Conclusion}

This work has demonstrated that, despite the benefits of requiring that states make public the consent upon which interventions are based, there is no such requirement, either within the rules of state responsibility or the law on the use of force. Though many states have publicised the consensual basis for interventions, these have been so varied that it seems there is no possibility of establishing a publicity requirement within customary international law.

In addition to this doctrinal conclusion, this paper has sought to demonstrate that, due to the lack of modality within intervention by invitation, the law is complicit in the proliferation and legitimising of liquid warfare. Taking the example of the US in Pakistan, consent has provided a way for at least nine years of airstrikes to be carried out in secret, with numerous civilians killed, but which can nevertheless be described as lawful, at least insofar as the resort to their use.

Ultimately, intervention by invitation is a doctrine with the clear capacity to act as a legal tool of neo-colonial policing and militarism, engendering modern practices of liquid warfare and entrenching hegemony. The absence of modalities in general, and the absence of a publicity requirement in particular, means that intervention by invitation should not be viewed as providing an adequate check on the use of force. Instead it provides states with a neat way of carrying out extraterritorial military operations in secret with the knowledge that, if necessary, the lawfulness of the intervention can be proclaimed. From the perspective of those, like me, who would seek to reduce the ease with which states can use military force, intervention by invitation, as it stands, is effectively bankrupt.

This means that, where intervention by invitation is presented as providing the basis for an intervention, it should be challenged. There is a need to resist the legitimising power of consent, to problematise its use as a catch-all legal justification for intervention across the globe. There should be no suggestion that consent renders an intervention 'perfectly' legal, and, even more so, where consent is presented as a basis for lawfulness it should not be equated with legitimacy.

\footnotetext{
${ }^{169}$ National Assembly of Pakistan, Resolution on Unilateral US Forces Action in Abbottabad on $2^{\text {nd }}$ May 2011 (14 May 2011) http://www.na.gov.pk/en/resolution detail.php?id=52.

170 Many thanks to Rob Knox for highlighting the 'aggregation of sovereignty' within consent, an idea with great scope for future analysis.
} 
In the era of liquid warfare, intervention by invitation must be seen for what it is. As well as rejecting the notion of legitimacy that comes with the imprimatur of lawfulness, it is also necessary to highlight the need to resist interventions by invitation through other means, recognising the compromised power of the law governing the resort to force. However, if intervention by invitation is to be resuscitated, that is if it is to stand any chance of actually providing a check on the use of force rather than enabling it, then perhaps attempting to develop a requirement that states publicise the fact that they are relying on consent, or indeed have given consent, in the manner of the IDI resolution, might not be a bad place to begin. 